\title{
Klasifikasi Kesalahan Siswa Kelas VII menggunakan Model KIAT tentang Materi Himpunan
}

\author{
Wahyu Sulistio $^{1}$, Gatot Muhsetyo ${ }^{1}$, Abdul Qohar ${ }^{1}$ \\ ${ }^{1}$ Pendidikan Matematika-Universitas Negeri Malang
}

\begin{tabular}{l}
\hline INFO ARTIKEL \\
\hline Riwayat Artikel: \\
Diterima: $30-04-2019$ \\
Disetujui: $20-06-2019$ \\
\hline
\end{tabular}

\section{Kata kunci:}

error classification;

set;

KIAT model;

klasifikasi kesalahan;

himpunan;

model KIAT

\author{
Alamat Korespondensi: \\ Wahyu Sulistio \\ Pendidikan Matematika \\ Universitas Negeri Malang \\ Jalan Semarang 5 Malang \\ E-mail: wahyusulistio56@gmail.com
}

\begin{abstract}
ABSTRAK
Abstract: Purpose of this study was to classify an errors made by 7 th grade students using the KIAT model of sets. Subjects in this study were 23 students. Procedure in this study is (1) makes a test question, (2) performs the validation, (3) performs the test, (4) does the error analysis, and (5) performs the error classification. Results of this study indicate that there are 5 categories of errors made by the subjects (1) type 1 conceptual error; (2) type 2 conceptual error; (3) procedural errors; (4) type 1 technical error; (5) type 2 technical error.

Abstrak: Tujuan dari penelitian ini adalah melakukan klasifikasi kesalahan yang dilakukan oleh siswa kelas VII menggunakan model KIAT tentang materi himpunan. Subjek pada penelitian ini adalah 23 siswa kelas VII. Prosedur pada penelitian ini adalah peneliti (1) membuat soal tes, (2) melakukan validasi, (3) melakukan tes, (4) melakukan analisis kesalahan, dan (5) melakukan klasifikasi kesalahan. Hasil dari penelitian ini menunjukkan bahwa ada lima kategori kesalahan yang dilakukan oleh subjek penelitian, yaitu (1) kesalahan konseptual tipe 1; (2) kesalahan konseptual tipe 2; (3) kesalahan prosedural; (4) kesalahan teknis tipe 1; (5) kesalahan teknis tipe 2.
\end{abstract}

Materi himpunan merupakan salah satu materi dalam matematika yang diajarkan secara terus menerus mulai dari Sekolah Dasar sampai dengan Sekolah Menengah Atas. Dipelajarinya materi himpunan untuk semua tingkatan sekolah ini sejalan dengan (NCTM, 2004), bahwa materi himpunan merupakan salah satu standard isi dari matematika sekolah. Oleh karena itu, mempelajari dan menguasai materi himpunan tentunya sangat penting untuk siswa. Akan tetapi, pada kenyataanya masih banyak siswa yang melakukan kesalahan apabila diminta untuk menyelesaikan soal materi himpunan. Banyaknya kesalahan yang dilakukan oleh siswa ini sejalan dengan pendapat (Patricia, 2017), bahwa masih banyak siswa yang melakukan kesalahan dalam menyelesaikan soal himpunan.

Kesalahan adalah penyimpangan dari sesuatu yang benar. (Egodawatte, 2011) bependapat bahwa kesalahan adalah penyimpangan dari solusi yang benar. (Chamudeswari, 2014) bahwa kesalahan adalah penyimpangan dari konsep yang benar . (Li, 2006) berpendapat, kesalahan adalah gejala kesalahpahaman yang nantinya akan menjadi suatu kesalahan. (Loc \& Hoc, 2014) berpendapat bahwa, kesalahan merupakan penyimpangan terhadap keakuratan atau ketidaktepatan. Menurut (Kaseri, 2013) kesalahan dalam mempelajari matematika adalah suatu penyimpangan yang dilakukan dalam menjawab soal matematika. (Young \& O’shea, 1981) berpendapat bahwa, kesalahan dalam matematika adalah penyimpangan dari solusi yang tepat, secara konsep maupun prosedur penyelesaian. (Nasser \& Carifio, 1993) menyatakan bahwa kesalahan yang banyak muncul dalam matematika adalah kesalahan prosedural dan kesalahan dalam perhitungan. (Lemer dalam Mulyono, 2009) juga mengemukakan bahwa beberapa kesalahan yang umum dilakukan oleh siswa dalam mengerjakan pemrmasalahan matematika yaitu kurangnnya pengetahuan tentang simbol, penggunaan langkah yang salah, dan kesalahan dalam perhitungan.

Kesalahan yang muncul pada saat siswa menyelesaikan permasalahan materi himpunan misalnya, siswa salah dalam menyajikan himpunan menggunakan notasi pembentuk himpunan, siswa salah dalam menentukan antara anggota himpunan dengan himpunan bagian. Beberapa penelitian terkait kesalahan yang dilakukan siswa dalam menyelesaikan soal (Bolyard \& Moyer-Packenham, 2016; Brown \& Kim, 2016; Kousathana \& Tsarpalist, 2002) menunjukkan bahwa kesalahan siswa disebabkan oleh kurangnya pemahaman siswa terhadap konsep matematika yang digunakan dalam menyelesaiakan soal atau dikarenakan siswa kurang memahami simbol matematis yang ada pada soal. Kesalahan dalam menyelesaikan soal himpunan juga disempaikan oleh (Patricia, 2017), contoh kesalahan yang dilakukan oleh siswa adalah kesalahan dalam menyajikan himpunan dengan Diagram Venn, kesalahan memasukkan anggota himpunan pada Diagram Venn. 
Berdasarkan adanya kesalahan siswa dalam menyelesaikan soal pada materi himpunan, peneliti pada artikel ini akan mengklasifikasikan kesalahan siswa kelas VII pada materi himpunan. Untuk mengklasifikasikan kesalahan yang terjadi pada siswa, dilakukan analisis kesalahan. Menurut (Herholdt \& Sapire, 2014) analisis kesalahan adalah studi tentang kesalahan dalam pekerjaan siswa dengan maksud untuk mencari penjelasan tentang suatu kesalahan tersebut. (Brown \& Kim, 2016) menyatakan bahwa analisis kesalahan merupakan penilaian diagnotik yang dapat digunakan guru untuk menentukan jenis kesalahan yang dilakukan oleh siswa dan penyebabnya. Ada beberapa metode untuk menganalisis dan mengklasifikasikan kesalahan siswa. Metode tersebut di antaranya adalah (Clements, 1980; Fong, 1993; Kiat, 2005; Newman, 1997; Watson, 1980). Diantara metode tersebut, metode milik Kiat dipilih karena lebih sederhana dan sesuai untuk menganalisis dan mengklasifikasikan kesalahan.

Kiat (2005) mengklasifikasikan kesalahan yang dilakukan siswa menjadi tiga kategori, yaitu (1) kesalahan konseptual, yaitu kesalahan yang terjadi karena siswa tidak memahami konsep-konsep yang terlibat dalam masalah atau kesalahan yang timbul dari ketidakmampuan siswa untuk menentukan hubungan yang terlibat dalam masalah; (2) kesalahan prosedural, yaitu kesalahan karena ketidakmampuan siswa untuk melakukan manipulasi atau algoritma meskipun telah memahami konsep dibalik masalah; (3) kesalahan teknis, yaitu kesalahan karena kurangnya pengetahuan konten matematika dalam topik lain atau kesalahan karena kecerobohan.

\section{METODE}

Subjek pada penelitian ini adalah 23 siswa kelas VII A MTs Roudlotul Muta'alimin. Pemilihan lokasi penelitian ini didasarkan pada beberapa alasan yaitu, belum pernah dilaksanakannya penelitian sejenis di lokasi tersebut, adanya dukungan dari kepala sekolah dan guru matematika, serta masih banyaknya siswa yang mengalami kesalahan dalam mengerjakan soal materi himpunan. Sumber data utama pada penelitian ini adalah hasil pekerjaan 23 siswa kelas VII A untuk soal yang diberikan dan didukung dengan hasil pengamatan dari peneliti selama proses pengerjaan soal tes.

Tahap tahap yang dilaksanakan pada penelitian ini, meliputi (1) peneliti menyusun instrumen penelitain berupa soal tes materi himpunan (Gambar 1) yang kemudian didiskusikan dengan guru matematika agar mendapatkan instrumen yang sesuai, (2) melaksanakan tes menggunakan instrumen yang sudah dibuat, dan (3) melaksanakan analisis data yang diperoleh dari tes terhadap 23 siswa. Analisis data ini dilaksanakan untuk mengetahui jenis kesalahan apa saja yang dilakukan oleh siswa tersebut dan kemudian diklasifikasikan berdasarkan jenis kesalahan yang sejenis.

\section{Kerjakan Soal Berikut dengen Lengiap}
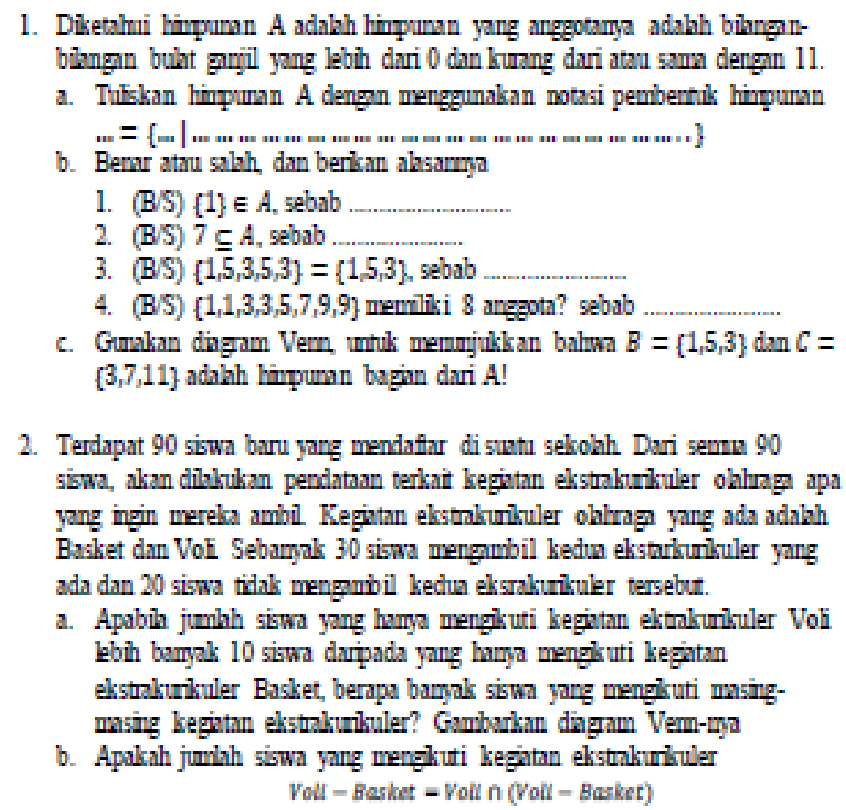

\section{Gambar 1. Soal Tes}

Analisis dan klasifikasi kesalahan pada penelitian ini didasarkan dengan analisis dan klasifikasi kesalahan oleh Kiat (2005) mengklasifikasikan kesalahan menjadi tiga, yaitu (1) kesalahan konseptual; (2) kesalahan prosedural; (3) kesalahan teknis. Secara lengkap, klasifikasi menurut KIAT dan contoh jenis kesalaahan yang dapat digunakan untuk mengklasifikasikan jenis kesalaahn dapat dilihat pada tabel 1 . 
Tabel 1. Klasifikasi Kesalahan Berdasarkan Kiat

\begin{tabular}{lll}
\hline \multicolumn{1}{c}{$\begin{array}{c}\text { Jenis } \\
\text { Kesalahan }\end{array}$} & \multicolumn{1}{c}{ Kategori Kesalahan } & \multicolumn{1}{c}{ Contoh Kesalahan } \\
\hline $\begin{array}{l}\text { Kesalahan } \\
\text { Konseptual }\end{array}$ & $\begin{array}{l}\text { Kesalahan yang terjadi karena siswa tidak memahami konsep- } \\
\text { konsep yang terlibat dalam masalah (K1) }\end{array}$ & Kesalahan memasukkan elemen dalam himpunan \\
\cline { 2 - 3 } & $\begin{array}{l}\text { Kesalahan yang timbul dari ketidakmampuan siswa untuk } \\
\text { menentukan hubungan yang terlibat dalam masalah (K2) }\end{array}$ & $\begin{array}{l}\text { Kesalahan dalam menuliskan antara himpunan } \\
\text { dan elemen himpunan }\end{array}$ \\
\hline $\begin{array}{l}\text { Kesalahan } \\
\text { Prosedural }\end{array}$ & $\begin{array}{l}\text { kesalahan karena ketidakmampuan siswa untuk melakukan } \\
\text { manipulasi atau algoritma meskipun telah memahami konsep } \\
\text { dibalik masalah (P) }\end{array}$ & $\begin{array}{l}\text { kesalahan pemilihan rumus dalam menyelesaikan } \\
\text { permasalahan } \\
\text { kesalahan dalam menggambar diagram Venn } \\
\text { (tidak terdapat persegi panjang yang merupakan } \\
\text { daerah semesta }\end{array}$ \\
\hline $\begin{array}{l}\text { Kesalahan } \\
\text { Teknis }\end{array}$ & $\begin{array}{l}\text { Kesalahan karena kurangnya pengetahuan konten matematika } \\
\text { dalam topik lain (T1) }\end{array}$ & $\begin{array}{l}\text { Tidak menyelesaikan hasil pekerjaan } \\
\text { Kesalahan karena kecerobohan (T2) }\end{array}$ \\
\cline { 2 - 3 } & Kesagram Verikan nama pada himpunan pada \\
\hline
\end{tabular}

\section{HASIL}

Penelitian ini dilaksanakan pada hari rabu tanggal 30 januari 2019. Penelitian ini dilaksanakan dengan cara memberikan soal tes kepada 23 siswa kelas VII A dengan durasi waktu mengerjakan 60 menit. Setelah siswa selesai mengerjakan soal yang diberikan, berikut adalah contoh hasil pekerjaan yang dilakukan oleh siswa. Gambar 2 menunjukkan hasil pekerjaan siswa untuk soal nomor 1 dan gambar 3 menunjukkan hasil pekerjaan siswa untuk nomor 2.

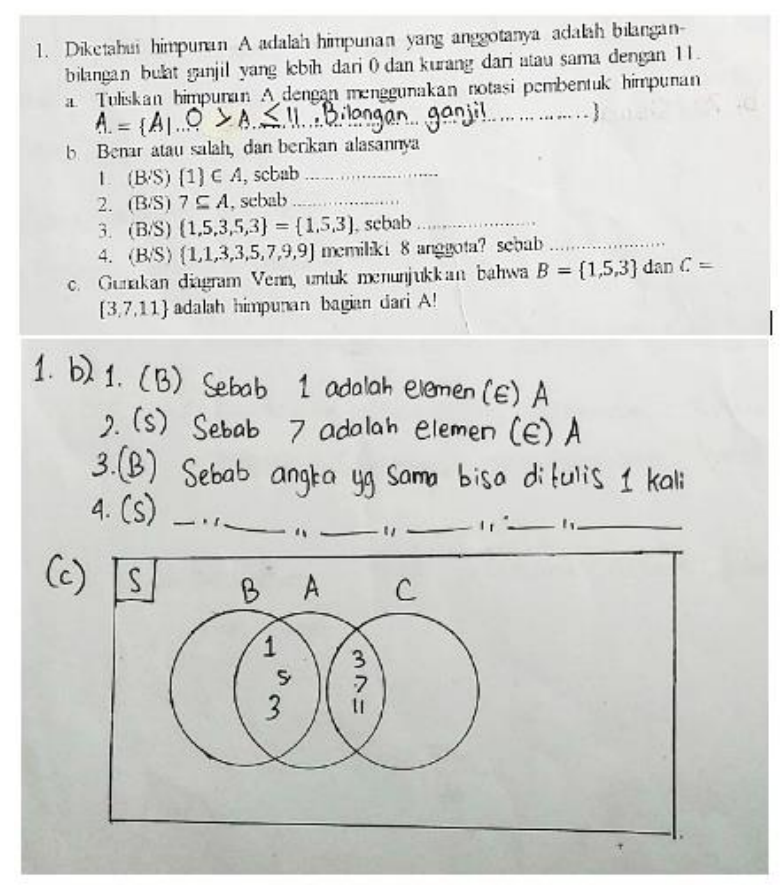

\section{Gambar 2. Hasil Pekerjaan Siswa untuk Nomor 1}

Berdasasarkan pekerjaan subjek pada soal nomor 1 (Gambar 2), didapatkan informasi dimana subjek untuk soal 1a sudah mampu menjawab pertanyaan dengan jawaban yang benar. Akan tetapi, terdapat sedikit kesalahan yaitu subjek tidak membedakan antara penggunaan notasi untuk himpunan dengan notasi untuk anggota himpunan. Subjek menuliskan notasi untuk anggota himpunan dengan menggunakan huruf kapital. Subjek untuk soal nomor 1a diklasifikasikan ke dalam kesalahan konseptual. Untuk soal $1 \mathrm{~b}$ subjek hanya melakukan kesalahan pada soal $1 \mathrm{~b}$, dimana subjek tidak dapat membedakan antara anggota dari suatu himpunan dengan himpunan bagian dari suatu himpunan. Subjek salah dalam memberikan alasan dengan menyebutkan bahwa $\{1\}$ adalah anggota dari A sehingga untuk soal nomor 1b satu subjek diklasifikasikan ke dalam kesalahan konseptual.

Kesalahan juga terjadi pada soal 1c dimana dia kurang memahami bagaimana cara penyajian beberapa himpunan yang memiliki anggota yang sama. Untuk soal 1c diklasifikasikan kedalam kesalahan konseptual. Selain itu, untuk soal 1c, subjek juga melakukan kesalahan dalam pemilihan cara untuk menyelesaikan masalah yang ada. Sehingga juga diklasifikasikan ke dalam kesalahan prosedural. 


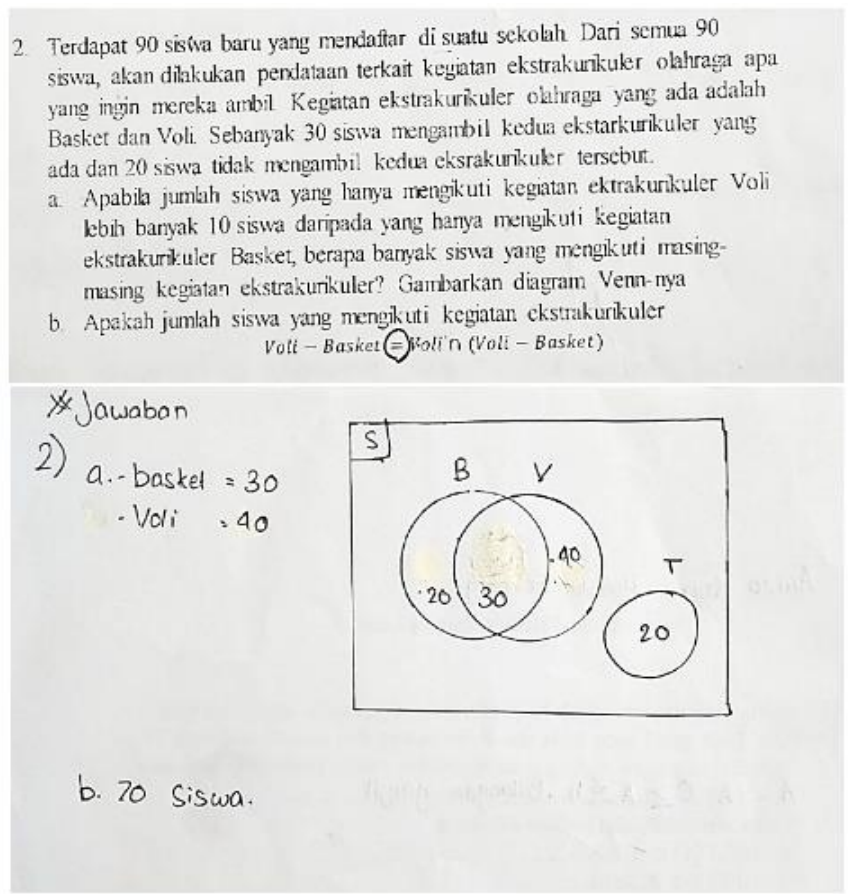

Gambar 3. Hasil Pekerjaan Siswa untuk Nomor 2

Untuk soal nomor 2 (Gambar 3), didapatkan informasi bahwa subjek untuk soal 2a mengalami kesalahan dalam menentukan jumlah anggota dari suatu himpunan dan kesalahan dalam memahami maksud dari permasalahan yang diberikan. "Subjek memasukkan angka 40 siswa yang mengikuti Voli dan 20 siswa yang mengikuti Basket yang selisish antara siswa yang ikut adalah 20", sementara pada soal yang diminta selisish antara yang mengikuti kedua ekstra tersebut adalah "10". Sehingga untuk soal 2a subjek diklasifikasikan kedalam kesalahan prosedural dan teknik tipe 2. Pada soal 2b subjek langsung menuliskan jawaban dari permasalahan yang diberikan dengan salah dan tidak sesuai dengan maksud dari permasalahan yang diberikan, sehingga untuk soal $2 \mathrm{~b}$ diklasifikasikan ke dalam kesalahan teknis. Berdasarkan contoh hasil analisis yang dilakukan kepada siswa yang dipilih, kemudian dilaksanakan analisis data yang sama untuk 22 siswa lainnya yang mengerjakan soal tes. Kemudian hasil analisi tersebut diklasifikasikan seperti pada tabel 2.

Tabel 2. Hasil Klasifikasi Kesalahan Subjek

\begin{tabular}{|c|c|c|c|c|c|c|c|}
\hline \multirow{2}{*}{ No Soal } & \multicolumn{2}{|c|}{ Kesalahan Konsep } & \multirow{2}{*}{ Kesalahan Prosedur } & \multicolumn{2}{|c|}{ Kesalahan Teknik } & \multirow{2}{*}{ Tidak Ada Kesalahan } & \multirow{2}{*}{ Tidak Menjawab } \\
\hline & Tipe 1 & Tipe 2 & & Tipe 1 & Tipe 2 & & \\
\hline $1 \mathrm{a}$ & 20 & - & - & - & 2 & & 2 \\
\hline 1b1 & 9 & 12 & & & & 2 & \\
\hline 1b2 & 13 & 7 & & & 1 & 2 & \\
\hline $1 \mathrm{b3}$ & 4 & 11 & & & & 8 & \\
\hline 1b4 & 7 & 7 & & & 3 & 6 & \\
\hline $1 \mathrm{c}$ & 20 & & 20 & 16 & 1 & & 3 \\
\hline $2 a$ & 6 & & 12 & 4 & 3 & & 11 \\
\hline $2 \mathrm{~b}$ & & & & 11 & & & 12 \\
\hline
\end{tabular}

\section{PEMBAHASAN}

\section{Kategori Kesalahan Konsep Tipe 1}

Kategori kesalahan konsep tipe 1 (kesalahan karena siswa tidak memahami konsep yang terkait dengan masalah), ditemukan hampir pada semua siswa yang mengerjakan soal tes, kesalahan konsep tipe 1 dijumpai pada soal nomor 1 dan 2 . Siswa dikategorikan ke dalam kesalahan ini dikarenakan siswa tersebut tidak memahami konsep dari materi yang diperlukan untuk menjawab soal. Salah satu contoh terkait kesalahan tipe ini adalah pada soal 1a, subjek penelitian melakukan kesalahan dalam melakukan penyajian himpunan dengan menggunakan notasi pembentuk himpunan. Siswa menjawab $A=\{A \mid 0<A \leq$ 11, Bilangan Ganjil $\}$ dimana seharusnya jawaban yang benar adalah $A=\{a \mid 0<a \leq 11$,Bilangan Ganjil $\}$ sehingga dapat dikatakan bahwa siswa kurang memahami konsep terkait teknik penyajian himpunan. Kesalahan karena tidak memahami konsep ini sejalan dengan pendapat (Roselizawati, Sarwadi, \& Shahril, 2014) kesalahan siswa dapat mencerminkan pemahamannya terhadap konsep matematika yang digunakan untuk menjawab soal matematika. 


\section{Kategori Kesalahan Konsep Tipe 2}

Kategori kesalahan konsep tipe 2 (kesalahan karena siswa tidak mampu untuk menentukan hubungan yang terlibat dalam masalah) ditemukan pada soal nomor 1b. Siswa dikategori kedalam kesalahan ini dikarenakan siswa sudah mampu menjawab pertanyaan dengan benar, akan tetapi siswa melakukan kesalahan dalam memberikan alasan terkait dengan jawaban mereka. Salah satu contoh kesalahan tipe ini ada pada soal nomor 1b3, siswa menjawab "Benar, sebab termasuk anggota himpunan A", sementara jawaban yang seharusnya adalah "Benar, karena pada penulisan anggota dari suatu himpunan apabila ada dua atau lebih anggota yang sama, maka penulisannya dapat disederhanakan". Berdasarkan hasil wawancara, beberapa siswa mengungkapkan bahwa mereka lupa dengan alasan yang harus mereka berikan sehingga mereka salah dalam memberikan alasan. Ketidakmampuan subjek untuk menentukan hubungan yang terlibat dalam masalah sejalan dengan (Shandu, 2013) kesalahan terjadi ketika siswa tahu apa yang harus mereka lakukan, tetapi salah dalam langkah selanjutnya.

\section{Kategori Kesalahan Prosedural}

Kategori kesalahan prosedural banyak ditemukan pada siswa untuk soal nomor 1c dan 2a. Kategori kesalahan ini terjadi karena siswa sebenarnya sudah memahami konsep dari permasalahan yang ada, akan tetapi mereka salah dalam memilih cara mengerjaknnya. Contoh kesalahan kategori ini adalah dilakukan oleh siswa pada soal nomor 2a dimana siswa tersebut salah dalam memilih rumus dalam menjawab soal. Pada soal tersebut ditanyakan jumlah siswa yang mengikuti masing-masing ekstrakurikuler, akan tetapi kebanyakan siswa hanya menjawab siswa yang hanya mengikuti satu ekstrakurikuler saja. Salah satu contohnya adalah, subjek menjawab "Siswa yang mengikuti basket 30 dan siswa yang mengikuti voli 40", dimana subjek hanya menuliskan jawaban siswa yang hanya mengikuti salah satu ekstra tanpa memasukkan siswa yang mengikuti keduanya. Sementara jawaban yang seharusnya adalah "Siswa yang mengukuti basket 45 dan siswa yang mengikuti voli 55". Berdasarkan hasil pekerjaan dan dialog dengan subjek, dapat disimpulkan bahwa subjek mengalami kesalahan prosedural dalam menyelesaikan soal dimana subjek salah dalam memilih rumus untuk menjawab soal yang ada.

Kesalahan prosedural dalam memilih cara penyelesaian ini sejalan dengan pendapat (Lemer dalam Mulyono, 2009) bahwa beberapa kesalahan yang umum dalam mengerjakan soal matematika adalah kurang pengetahuan tentang simbol, penggunaan langkah yang keliru, kesalahan perhitungan. Selain karena salah memilih rumus, kesalahan prosedural juga dipengaruhi oleh kesalahan konseptual yang dilakukan siswa.

\section{Kategori Kesalahan Teknis Tipe 1}

Kategori kesalahan teknis tipe 1 (kesalahan karena kurang pemahaman terhadap tujuan dari permasalahan) banyak ditemukan pada subjek penelitian pada soal nomor 1c, 2a, dan 2b. Subjek dikategorikan ke dalam kesalahan ini dikarenakan subjek penelitian tidak mampu memahami tujuan dari permasalahan yang ada, sehingga subjek penelitian mampu mengerjakan tetapi tidak sampai menjawab pertanyaan yang diberikan. Kategori kesalahan ini sebenarnya juga mencakup apabila subjek tidak mengerjakan soal, tetapi dengan alasan karena tidak memahami maksud dari soal. Berdasarkan hasil pekerjaan dan wawancara dengan beberapa subjek yang terpilih didapatkan informasi bahwa subjek tersebut kurang begitu memahami tujuan dari soal yang diberikan sehingga dalam menjawab pertanyaan mereka mengalami kesalahan.

Contohnya yang terlihat pada soal $1 \mathrm{c}$ dan $2 \mathrm{~b}$ dimana subjek tersebut sudah menjawab pertanyaan, tetapi jawaban mereka tidak sesuai dengan yang diharapkan oleh soal. Salah satu contoh kesalahan tipe ini adalah subjek untuk soal nomor $2 b$ menjawab "70 siswa", sementara yang diminta oleh soal adalah menunjukkan apakah $V-B=V \cap(V-B)$. Kategori kesalahan teknis tipe 1 ini sejalan dengan pendapat (Knifong \& Holtan, 1976) bahwa siswa yang mampu membaca dan memahami soal bukan berarti dapat menyelesaiakan soal dengan benar. Lebih lanjut, (Pratiwi, 2011) menyatakan apabila siswa mampu menuliskan dengan tepat apa yang mereka ketahui dan ditanyakan pada soal, maka siswa tesebut dapat memahami maksud soal.

\section{Kategori Kesalahan Teknis Tipe 2}

Kategori kesalahan teknis tipe 2 (kesalahan karena kecerobohan) dijumpai pada subjek untuk soal nomor 1 dan pada 2a. subjek melakukan kesalahan dalam melakukan perhitungan banyaknya anggota himpunan yang berbeda dari suatu himpunan, sehingga menyebabkan jawabannya dikatakan salah. Sementara untuk soal 2a subjek juga kurang teliti dalam menentukan jumlah masukan yang harus ditulis pada diagram Venn walaupun mereka sebenarnya sudah mengetahui maksud dari soal. Salah satu contoh kesalahan tipe ini adalah "Subjek memasukkan angka 40 siswa yang mengikuti Voli dan 20 siswa yang mengikuti Basket yang selisish antara siswa yang ikut adalah 20", sementara pada soal yang diminta selisish antara yang mengikuti kedua ekstra tersebut adalah "10". Berdasarkan hasil wawancara yang dilakukan, ketiga subjek mengakui bahwa mereka memang kurang teliti dalam mengerjakan soal tersebut karena terburu-buru. Kategori kesalahan karena kecerobohan ini sejalan dengan pendapat (Sammons \& Windham, 2011) bahwa kesalahan kecerobohan biasanya dilakukan oleh siswa yang sebetulnya memahami konsep yang digunakan dalam menjawab soal, tetapi jawaban yang diperoleh menjadi kurang sesuai karena siswa tersebut terburu-buru dan tidak teliti. Selain itu, (Ben-Zeev \& Star, 2002) juga menyatakan bahwa kesalahan kecerobohan adalah kesalahan yang dilakukan siswa karena kurang teliti dalam melakukan perhitungan dalam mengerjakan soal. 


\section{SIMPULAN}

Kesalahan konseptual berdasarkan model KIAT yang muncul dalam menyelesaikan soal himpunan adalah (1) kesalahan konseptual tipe 1, dimana subjek kurang memahami konsep yang terkait dengan masalah yang diberikan dan (2) kesalahan konseptual tipe 2, dimana subjek penelitian tidak mampu menentukan hubungan yang terlibat dalam masalah sehingga subjek dapat menjawab pertanyaan dengan benar, tetapi memberikan alasan yang tidak sesuai dengan jawabannya. Kesalahan prosedural berdasarkan model KIAT yang muncul dalam menyelesaikan soal himpunan yaitu, subjek penelitian sudah memahami konsep terkait masalah yang diberikan, tetapi tidak mampu untuk melakukan manipulasi berupa memilih rumus yang sesuai untuk menyelesaikan masalah yang ada.

Kesalahan teknik berdasarkan model KIAT yang muncul dalam menyelesaikan soal himpunan, meliputi (1) kesalahan teknik tipe 1, dimana subjek tidak menyelesaikan pekerjaannya dan tidak menjawab dengan sesuai dengan permintaan dari soal dikarenakan tidak memahami maksud dari pertanyaan dan (2) kesalahan teknik tipe 2, dimana subjek penelitian melakukan kecerobohan dalam menyelesaikan soal yang diberikan dikarenakan subjek tersebut terburu-buru dan tidak teliti.

Berdasarkan temuan pada penelitian ini, diharapkan guru dapat mencari cara melaksanakan pembelajaran yang lebih sesuai dengan siswa, agar siswa lebih mampu dan mudah dalam memahami materi himpunan dan guru juga diharapkan mampu membuat siswa tidak hanya belajar dengan menghafal. Untuk siswa juga diharapkan dapat memperbaiki cara belajar mereka sehingga dapat mengurangi tingkat kesalahan yang mereka lakukan.

\section{DAFTAR RUJUKAN}

Ben-Zeev, T \& Star, J. (2002). Intuitive Mathematics: Theoretical and Educational Implication. New York: Routledge.

Bolyard, J.J. \& Moyer-Packenham, P. S. (2016). Revisiting the Definition of a Virtual Manipulative. International Perspective on Teaching and Learning Mathematics with Virtual Manipulative, 3-23.

Chamudeswari, S. (2014). Conceptual Errors Encountered in Mathematichal Operation in Algebra among Students at the Secondary Level. International Journal of Innovative Science, 1(8), 24-38.

Egodawatte, G. (2011). Secondary School Student's Misconceptions in Algebra. Unpublished Dissertation. University of Toronto, Toronto.

Fong, H. (1993). Schematic Model for Categorizing Children's Errors in Mathematics. The Proceedings of Third International Seminar on Misconceprtions and Educational Strategies in Science and Mathematics.

Herholdt, R., \& Sapire, I. (2014). An Errors Analysis in The Early Grades Mathematics-A Learning Opportunity?. South African Journal of Childhood Education, 4(1), 42-60.

Li, X. (2006). Cognitive Analysis of Student's Errors and Misconception in Variables, Equation, and Function. Unpublished Dissertation. Texas A \& M University.

Loc, N. P., \& Hoc, T. C. T. (2014). A Survey of 12th Grade Students' Errors in Solving Calculus Problem. International Journal of Scientific \& Technology Research, 3(6).

Kaseri. (2013). Analisis Kesalahan Dalam Menyelesaikan Soal Program Linier Siswa Kelas X SMK Negeri Gudo Jombang Tahun 2012/2013. Tesis tidak diterbitkan. Universitas Negeri Malang, Malang.

Kiat, S. E. (2005). Analysis of Students' Difficulties in Solving Integration Problems. The Mathematics Educator, 9(1), 39-59.

Kousathana, M., \& Tsarpalist, G. (2002). Students' Errors in Solving Numerical Chemical-Equilibrium Problems. Journal of Chemistry Education: Research adn Practice in Europe, 3(1), 5-17.

Mulyono, A. (2009). Pendidikan bagi Anak Berkesulitan Belajar. Jakarta: Rineka Cipta.

Nasser, R., \& Carifio, J. (1993). Students Misconceptional and Errors Insolving Algebra Word Problems Related to Misconceptions in the Field of Science. Proceeding of the Third International Seminar on Misconceptions and Educational Strategies in Science and Mathematics, Misconception Trust. Ithaca, August 1-4.

Newman, M. A. (1997). An Analysis of Sixth-Grade Pupils's Errors on Writen Mathematics Tasks. Research in Mathematical Education in Australia, 1, 239-258.

Patricia, F. A. (2017). Analisis Kesalahan Mahasiswa Program Studi Pendidikan Matematika IKIP Budi Utomo Malang berdasarkan Gender dalam Menyelesaikan Himpunan. APOTEMA: Jurnal Program Studi Pendidikan Matematika, 3(2), $45-52$

Pratiwi, E. (2011). Analisis Perilaku dan Kesalahan Siswa Kelas IV dalam Memecahkan Soal Cerita Matematika berdasarkan Tahapan Analisis Kesalahan Newman. Tesis tidak diterbitkan. Universitas Negeri Malang, Malang.

Roselizawati, Sarwadi, \& Shahrill, M. (2014). Understanding Student's Matheamtical Errors and Misconceptions: The Case of Year 11 Repeating Students. Mathematics Education Trends and Research, 1-10. doi: 10.5899/2014/metr-00051.

Watson, I. (1980). Investigating Errors of Beginning Mathematics. Education Studies in Mathematics, 319-329.

Young, R., \& O'shea, T. (1981). Errors in Childrens Substraction. Cognitive Science, 5(2), 152-177. 